\title{
The balance between closed and open forms of spiropyrans in the solid state
}

\author{
Christer B. Aakeröy, ${ }^{a}$ Evan P. Hurley, ${ }^{a}$ John Desper, ${ }^{a}$ Manuel Natali, ${ }^{b}$ Antoin Douglawi, ${ }^{b}$ and Silvia \\ Giordani*b $^{\mathbf{b}}$
}

Received (in XXX, XXX) 1st January 2007, Accepted 1st January 2007

First published on the web 1st January 2007

5 DOI: 10.1039/b000000x

We present three new crystal structures of members from the photochromic spiropyran family, including a rare example of an open (merocyanine) form. The molecular structures are systematically compared with existing crystallographically 10 relevant data, and a new avenue for stabilizing open spiropyran forms in the solid-state is postulated.

\section{Introduction}

The photochromic behaviour of spiropyrans has been known for over fifty years, ${ }^{1}$ and their intriguing properties and 15 potential applications as sensors, ${ }^{2}$ molecular switches, ${ }^{3}$ erasable memories, ${ }^{4}$ etc., have ensured that they are of considerable interest to a broad spectrum of scientists. ${ }^{5}$

Spiropyrans tend to absorb light in the 200-400 $\mathrm{nm}$ range, which can produce bond-cleavage resulting in an open 20 merocyanine form; the reversibility of this transformation can normally be attained via either thermal or photochemical means, Scheme 1.6
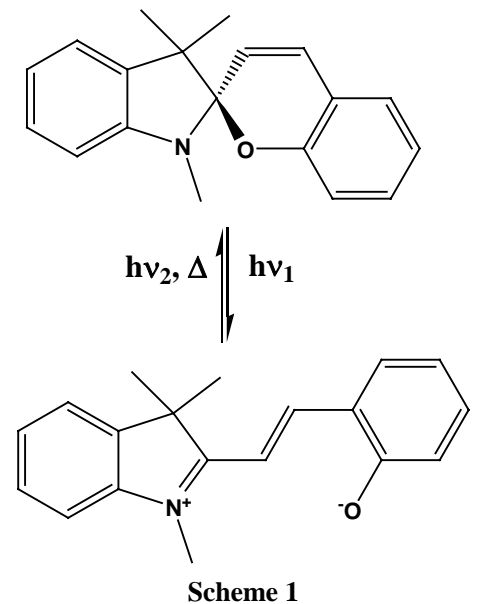

${ }_{25}$ The exact photochemical behavior and absorption/emission profiles of the open forms (usually deeply coloured) as well as of the closed forms (usually colourless), depend critically on the type/position of substituent around the benzopyran and the indole backbone, ${ }^{7}$ as well as on the polarity of the solvent. ${ }^{8}$

${ }_{30}$ Furthermore, the addition of suitable substituents in appropriate positions may also affect stability, solubility and metal-binding ability. ${ }^{9}$

Merocyanine conformations are important for understanding decomposition and ring-closure processes. Although most 35 photochromic work on spiropyrans has been done in solution, there have been some reports on the solid-state photochemical behaviour of this family of compounds. ${ }^{10}$ In order to better understand how the balance between open and closed forms may be controlled or influenced by intermolecular interactions 40 in the solid-state, we have embarked upon a systematic synthetic-structural program with a view to examining how different substituents affect the precise molecular geometry (and thus photochemical behaviour) of the spiropyran molecule. We are particularly interested in how the open 45 merocyanine form may be stabilized and such a structural study can inform the subsequent design of a wide range of chemosensory devices geared towards selective recognition and binding of metal ions. Despite the fact that spiropyrans have been extensively studied (a SciFinder search produces 50 over 2000 entries), a mere 36 crystal structures ${ }^{11}$ have been reported, only four of which are for the open-form merocyanine. ${ }^{12,13,14}$ In order to establish potential connections between molecular geometry, photochromic behaviour, and sold-state structures, we have synthesized 55 three spiropyran derivatives ethyl-4-(3',3'-dimethyl-6nitrospiro[chromene-2,2'-indoline]-1'-yl)butanoate, 2, 4-(8methoxy-3',3'-dimethyl-6-nitrospiro[chromene-2,2'-indoline]1'-yl)butanoate, 3, and 2-(3',3'-dimethyl-6-nitro-3'Hspiro[chromene-2,2'-indol]-1'-yl)ethanol, 5, and analyzed their 60 structural features in the context of existing literature data.

\section{Experimental}

Synthesis of 1-(4-ethoxy-4-oxobutyl)-2,3,3-trimethyl-3H-indolium bromide, 1

${ }_{65}$ A solution of 2,3,3-trimethylindolenine ( $\left.8.49 \mathrm{mmol}, 1.36 \mathrm{ml}\right)$ and 4-bromobutyrate $(12.7 \mathrm{mmol}, 1.81 \mathrm{ml})$ in $20 \mathrm{ml}$ of chloroform was stirred under reflux for $24 \mathrm{~h}$. The solution was cooled to room temperature and the solvent was then evaporated. To the purple residue $1 \mathrm{ml}$ of methanol was added 70 and the product was crystallized from $20-30 \mathrm{ml}$ of diethyl ether affording $1.22 \mathrm{~g}$ of a pink powder, yield $43 \% .{ }^{1} \mathbf{H}-\mathbf{N M R}$ $\left(400 \mathrm{MHz}, \mathrm{CDCl}_{3}\right): \delta=1.19\left(\mathrm{t}, 3 \mathrm{H}, J=7.04 \mathrm{~Hz}, \mathrm{CH}_{3}\right), 1.62(\mathrm{~s}$, $\left.6 \mathrm{H},\left(\mathrm{CH}_{3}\right)_{2}\right), 2.21-2.27\left(\mathrm{~m}, 2 \mathrm{H}, \mathrm{CH}_{2}\right), 2.70(\mathrm{t}, 2 \mathrm{H}, J=5.84 \mathrm{~Hz}$, $\left.\mathrm{CH}_{2}\right), 3.17\left(\mathrm{~s}, 3 \mathrm{H}, \mathrm{CH}_{3}\right), 4.02(\mathrm{q}, 2 \mathrm{H}, J=7.6 \mathrm{~Hz}$ and $14.6 \mathrm{~Hz}$, ${ }_{75} \mathrm{CH}_{2}$ ), 4.86 (t, 2H, J=8 Hz, $\mathrm{CH}_{2}$ ), 7.53-7.60 (m, 3H, arom.), 8.01-8.10 (m, 1H, arom.). ${ }^{13} \mathrm{C}-\mathrm{NMR}\left(100 \mathrm{MHz}, \mathrm{CDCl}_{3}\right)$ : $\delta=13.6\left(\mathrm{CH}_{3}\right), 15.7\left(\mathrm{CH}_{3}\right), 22.2\left(\mathrm{CH}_{2}\right), 22.4,22.6\left(\left(\mathrm{CH}_{3}\right)_{2}\right)$, $29.9\left(\mathrm{CH}_{2}\right), 48.0\left(\mathrm{C}\left(\mathrm{CH}_{3}\right)_{2}\right), 54.1\left(\mathrm{NCH}_{2}\right), 60.5\left(\mathrm{OCH}_{2} \mathrm{CH}_{3}\right)$, 115.4, 122.6, 129.1, 129.5, 140.7, 141.1 (arom.), 172.3 80 (COOEt), $195.9\left(\mathrm{NCCH}_{3}\right)$. 
Synthesis of ethyl4-(3',3'-dimethyl-6-nitrospiro[chromene-2,2'indoline]-1'-yl)butanoate, 2

A solution containing $0.60 \mathrm{~g}(1.69 \mathrm{mmol})$ of 1 and $0.34 \mathrm{~g}$ $(2.03 \mathrm{mmol})$ of 5-nitrosalicylaldehyde was added in $20 \mathrm{ml}$ of 5 absolute ethanol and refluxed for $24 \mathrm{~h}$. The solution was then cooled to r.t. and the dark purple mixture was further cooled in an ice bath and filtered. The filter cake was washed with cold ethanol yielding an orange solid which was dissolved in dichloromethane and washed with an aqueous solution of ${ }_{10} \mathrm{Na}_{2} \mathrm{CO}_{3}$. The organic layer was dried over $\mathrm{Na}_{2} \mathrm{SO}_{4}$ and the solvent was distilled at reduced pressure. Recrystallization from ethanol afforded $170 \mathrm{mg}$ of a pale yellow powder, yield 23\%. ${ }^{1} \mathrm{H}-\mathrm{NMR}\left(400 \mathrm{MHz}, \mathrm{CDCl}_{3}\right): \delta=1.21\left(\mathrm{~s}, 3 \mathrm{H}, \mathrm{CH}_{3}\right)$, 1.25 , (t, 3H, J=7.28 Hz, $\left.\mathrm{CH}_{3}\right), 1.31\left(\mathrm{~s}, 3 \mathrm{H}, \mathrm{CH}_{3}\right), 1.90-2.02$ $15\left(\mathrm{~m}, 2 \mathrm{H}, \mathrm{CH}_{2}\right), 2.35-2.40\left(\mathrm{~m}, 2 \mathrm{H}, \mathrm{CH}_{2}\right), 3.21-3.26(\mathrm{~m}, 2 \mathrm{H}$, $\left.\mathrm{CH}_{2}\right), 4.11-4.14\left(\mathrm{~m}, 2 \mathrm{H}, \mathrm{CH}_{2}\right), 5.89(\mathrm{~d}, 1 \mathrm{H}, \mathrm{J}=10.5 \mathrm{~Hz}, \mathrm{CH})$, $6.67(\mathrm{~d}, 1 \mathrm{H}, J=7.76 \mathrm{~Hz}$, arom.), $6.76(\mathrm{~d}, 1 \mathrm{H}, J=8.68 \mathrm{~Hz}$, arom.), 6.92 (d, 1H, J=10.5 Hz, CH), 6.93 (m, 1H, arom.) 7.12 (d, $1 \mathrm{H}, J=6.76 \mathrm{~Hz}$, arom.), 7.20-7.25 (m, 1H, arom.), 8.01208.05 (m, 2H, arom.). ${ }^{13} \mathrm{C}-\mathbf{N M R}\left(100 \mathrm{MHz}, \mathrm{CDCl}_{3}\right): \delta=14.2$ $\left(\mathrm{CH}_{3}\right), 19.9\left(\mathrm{CH}_{3}\right), 24.1\left(\mathrm{CH}_{3}\right), 25.9\left(\mathrm{CH}_{2}\right), 31.7\left(\mathrm{CH}_{2}\right), 43.1$ $\left(\mathrm{NCH}_{2}\right), \quad 52.6\left(\mathrm{C}\left(\mathrm{CH}_{3}\right)_{2}\right), \quad 60.5\left(\mathrm{OCH}_{2} \mathrm{CH}_{3}\right), 106.7,106.8$ (arom.), 115.6 (C spiro.), 118.4, 119.6, 121.7, 121.8, 122.7, 125.9, 127.8, 128.2, 135.9 (arom.), $140.9\left(\mathrm{CNO}_{2}\right), 147.0$ 25 (arom.), 159.5 (CO), 173.1 (COOEt). HRMS (m/z -ES) : Found: $423.1935\left(\mathrm{M}^{+}, \mathrm{C}_{24} \mathrm{H}_{26} \mathrm{~N}_{2} \mathrm{O}_{5}\right.$ Requires: 422.4808$)$, 445.1744 $\left(\mathrm{M}^{+}+\mathrm{Na}, \mathrm{C}_{24} \mathrm{H}_{26} \mathrm{~N}_{2} \mathrm{O}_{5} \mathrm{Na}\right.$, Requires: 445.4706). $\mathrm{v}$ $\left(\mathbf{c m}^{-\mathbf{1}}\right):$ 2962, 1732, 1510, 1479, 1332,1274, 1089, 952. mp : $116^{\circ} \mathrm{C}$. Crystal growth: To a small vial, $4.6 \mathrm{mg}(0.011 \mathrm{mmol})$ 30 of 2 was added along with $1 \mathrm{ml}$ of methanol. The vial was heated gently to afford a deep red solution. The solution was slowly evaporated at ambient conditions which produced colourless plates.

35 Synthesis of ethyl 4-(8-methoxy-3',3'-dimethyl-6nitrospiro[chromene-2,2'-indoline]-1'-yl)butanoate, 3

A solution containing $0.783 \mathrm{~g}(2.21 \mathrm{mmol})$ of 1 and $0.653 \mathrm{~g}$ (3.32 mmol) of 3-methoxy-5-nitrosalicylaldehyde in $20 \mathrm{ml}$ of ethanol was stirred at reflux for $24 \mathrm{~h}$. The solution was then 40 concentrated and kept in the freezer for $24 \mathrm{~h}$. A yellow powder was filtered off from the chilled solution and washed with cold ethanol. It was then dissolved in $30 \mathrm{ml}$ of dichloromethane, washed with a $10 \%$ aqueous solution of $\mathrm{Na}_{2} \mathrm{CO}_{3}$, dried over $\mathrm{Na}_{2} \mathrm{SO}_{4}$. The solvent was then distilled at 45 reduced pressure affording $351 \mathrm{mg}$ of a blue solid, yield $35 \%$.

${ }^{1} \mathbf{H}-\mathbf{N M R}\left(400 \mathrm{MHz}, \mathrm{CDCl}_{3}\right): \delta=1.19\left(\mathrm{~s}, 3 \mathrm{H}, \mathrm{CH}_{3}\right), 1.24(\mathrm{t}$, $\left.3 \mathrm{H}, J=4.32 \mathrm{~Hz}, \mathrm{CH}_{3}\right), 1.29,\left(\mathrm{~s}, 3 \mathrm{H}, \mathrm{CH}_{3}\right), 1.90-2.00(\mathrm{~m}, 2 \mathrm{H}$, $\left.\mathrm{CH}_{2}\right), 2.34-2.38\left(\mathrm{~m}, 2 \mathrm{H}, \mathrm{CH}_{2}\right), 3.25-3.27\left(\mathrm{~m}, 2 \mathrm{H}, \mathrm{CH}_{2}\right), 3.77$ $\left(\mathrm{s}, 3 \mathrm{H}, \mathrm{OCH}_{3}\right), 4.08-4.13\left(\mathrm{~m}, 2 \mathrm{H}, \mathrm{CH}_{2}\right), 5.85(\mathrm{~d}, 1 \mathrm{H}, \mathrm{J}=10.32$ $\left.{ }_{50} \mathrm{~Hz}, \mathrm{CH}\right), 6.64(\mathrm{~d}, 1 \mathrm{H}, J=7.76 \mathrm{~Hz}$, arom.), $6.85(\mathrm{~d}, 1 \mathrm{H}$, , $J=10.32 \mathrm{~Hz}, \mathrm{CH}), 6.88$ (m, H, arom.), 7.08 (d, $1 \mathrm{H}, J=7.2 \mathrm{~Hz}$, arom.), 7.20-7.28 (m, 1H, arom.), 7.63-7.70 (m, 2H, arom.). ${ }^{13}$ C-NMR $\left(100 \mathrm{MHz}, \mathrm{CDCl}_{3}\right): \delta=13.7\left(\mathrm{CH}_{3}\right), 19.5\left(\mathrm{CH}_{3}\right)$, $23.5\left(\mathrm{CH}_{3}\right), 25.5\left(\mathrm{CH}_{2}\right), 31.3\left(\mathrm{CH}_{2}\right), 42.5\left(\mathrm{NCH}_{2}\right), 52.2$

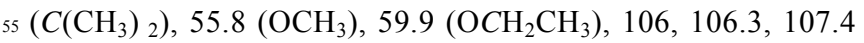
(arom.), 114.9 (C spiro.), 117.7, 118.9,121.2, 121.5, 127.2, 127.7, 135.5 (arom.), $139.9\left(\mathrm{CNO}_{2}\right), 146.5$ (arom.), 146.9 (COMe), 148.9 (CO), 172.7 (COOEt). HRMS (m/z -ES) : Found: $453.2023\left(\mathrm{M}^{+}, \mathrm{C}_{25} \mathrm{H}_{28} \mathrm{~N}_{2} \mathrm{O}_{6}\right.$ Requires: 452.5071),
${ }_{60} 475.1927\left(\mathrm{M}^{+}+\mathrm{Na}, \mathrm{C}_{25} \mathrm{H}_{28} \mathrm{~N}_{2} \mathrm{O}_{6} \mathrm{Na}\right.$, Requires: 475.4969). $\mathrm{v}$ $\left(\mathbf{c m}^{-1}\right): 2932,1733,1519,1479,1333,1270 . \mathbf{m p}: 123^{\circ} \mathrm{C}$. Crystal growth: To a small vial, $1 \mathrm{ml}$ of a $0.043 \mathrm{M}$ acetonitrile solution of 3 was combined with $1 \mathrm{ml}$ of methanol. The solution was slowly evaporated at ambient condition which ${ }_{65}$ produced colourless prisms.

Synthesis of 1-(2-hydroxyethyl)-2,3,3-trimethyl-3H-indolium bromide, 4

A solution of 2,3,3-trimethyl-3H-indole $(1.40 \mathrm{~g}, 8.8 \mathrm{mmol})$ 70 and 2-bromoethanol $(1.37 \mathrm{~g}, 10.9 \mathrm{mmol})$ in $\mathrm{CH}_{3} \mathrm{CN}(20 \mathrm{~mL})$ was heated for $24 \mathrm{~h}$ under reflux and $\mathrm{N}_{2}$. After cooling down to ambient temperature, the solvent was distilled off under reduced pressure. The residue was suspended in hexane (25 $\mathrm{mL}$ ) and the mixture was sonicated and filtered. The resulting 75 solid was crystallized from $\mathrm{CHCl}_{3}(35 \mathrm{~mL})$ to afford the product $(1.14 \mathrm{~g}, 46 \%)$ as a pink solid. ${ }^{\mathbf{1}} \mathbf{H}-\mathbf{N M R}(400 \mathrm{MHz}$, $\left.\mathrm{CD}_{3} \mathrm{CN}\right): \delta=7.83-7.75(1 \mathrm{H}, \mathrm{m}), 7.74-7.72(1 \mathrm{H}, \mathrm{m}), 7.65-$ $7.54(2 \mathrm{H}, \mathrm{m}), 4.82(1 \mathrm{H}, \mathrm{t}, \mathrm{J}=6 \mathrm{~Hz}), 4.54(2 \mathrm{H}, \mathrm{t}, \mathrm{J}=5 \mathrm{~Hz})$, 4.02-3.94 (2H, m), $2.81(3 \mathrm{H}, \mathrm{s}), 1.61(6 \mathrm{H}, \mathrm{s}) ;{ }^{13} \mathbf{C}-\mathbf{N M R}(100$ $\left.{ }_{80} \mathrm{MHz}, \mathrm{CD}_{3} \mathrm{CN}\right): \delta=198.84,141.99,141.42,129.71,129.03$, $123.33,115.54,57.80,54.67,50.86,21.93,14.61$.

Synthesis of 2-(3',3'-Dimethyl-6-nitro-3'H-spiro[chromene-2,2'indol]-1'-yl)ethanol, 5

85 A solution of 3-methoxy-2-hydroxy-5-nitrobenzaldehyde $(1.14 \mathrm{~g}, 4 \mathrm{mmol})$ and $4(0.87 \mathrm{~g}, 4 \mathrm{mmol})$ in EtOH $(20 \mathrm{~mL})$ was heated for $6 \mathrm{~h}$ under reflux and $\mathrm{N}_{2}$. After cooling down to ambient temperature, the mixture was filtered. The resulting solid was dissolved in dichloromethane, washed with $90 \mathrm{a} \mathrm{Na}_{2} \mathrm{CO}_{3}$ solution in water $(10 \%)$ and the organic phase was dried over $\mathrm{Na}_{2} \mathrm{SO} 4$. After evaporation of solvent $300 \mathrm{mg}$, $31 \%$ of 2 were obtained as a golden solid. ${ }^{\mathbf{1}} \mathbf{H}-\mathbf{N M R}(400$ $\left.\mathrm{MHz}, \mathrm{CD}_{3} \mathrm{CN}\right): \delta=7.79(1 \mathrm{H}, \mathrm{d}, \mathrm{J}=2.56 \mathrm{~Hz}), 7.69(1 \mathrm{H}, \mathrm{d}$, $\mathrm{J}=2.56 \mathrm{~Hz}), 7.17(1 \mathrm{H}, \mathrm{t}, \mathrm{J}=7.60 \mathrm{~Hz}), 7.14(2 \mathrm{H}, \mathrm{d}, \mathrm{J}=7.60 \mathrm{~Hz})$, $957.01(1 \mathrm{H}, \mathrm{d}, \mathrm{J}=10.4 \mathrm{~Hz}), 6.88(1 \mathrm{H}, \mathrm{d}, \mathrm{J}=7.36 \mathrm{~Hz}), 6.69(1 \mathrm{H}, \mathrm{d}$, $\mathrm{J}=7.8 \mathrm{~Hz}), 6.01(1 \mathrm{H}, \mathrm{d}, \mathrm{J}=10.4 \mathrm{~Hz}), 3.79(3 \mathrm{H}, \mathrm{s}), 3.67-3.41$ $(2 \mathrm{H}, \mathrm{m}), 3.39-3.22(2 \mathrm{H}, \mathrm{m}), 2.84(1 \mathrm{H}, \mathrm{bs}), 1.25(3 \mathrm{H}, \mathrm{s}), 1.16$ $(3 \mathrm{H}, \mathrm{s})$. HRMS (m/z -ES) : Found: $383.1608\left(\mathrm{M}^{+}+\mathrm{H}\right.$, $\mathrm{C}_{21} \mathrm{H}_{22} \mathrm{~N}_{2} \mathrm{O}_{5}$ Requires: 382.1529). Crystal growth: To a small 100 vial, $4.4 \mathrm{mg}(0.012 \mathrm{mmol})$ of 5 was added along with $1 \mathrm{ml}$ of methanol. The vial was heated gently to afford a deep purple solution and subsequently the solution was evaporated at ambient condition to produce purple prisms.

\section{$105 \mathrm{X}$-ray data}

Datasets were collected on Bruker Kappa APEX II systems using MoK $\alpha$ radiation. Data were collected using APEX2 software. ${ }^{15}$ Initial cell constants were found by small widely separated "matrix" runs. Data collection strategies were 110 determined using COSMO. Scan speed and scan width were chosen based on scattering power and peak rocking curves. All datasets were collected at $-153{ }^{\circ} \mathrm{C}$ using an Oxford Cryostream low-temperature device.

Unit cell constants and orientation matrix were improved by 115 least-squares refinement of reflections thresholded from the entire dataset. Integration was performed with SAINT, ${ }^{16}$ using this improved unit cell as a starting point. Precise unit cell constants were calculated in SAINT from the final merged 
dataset. Lorentz and polarization corrections were applied. Absorption corrections were not applied (in all cases $\mu * \mathrm{~d}<$ 0.025). Data were reduced with SHELXTL. ${ }^{17}$ The structures were solved in all cases by direct methods without incident. 5 All hydrogen atoms were assigned to idealized positions and were allowed to ride, with the exception of the hydroxyl proton $\mathrm{H} 23$ of 5 , whose coordinates were allowed to refine. 3 crystallized in the noncentrosymmetric space group Cc. Due to the absence of anomalous scatterers, no attempt was made 10 to determine absolute configuration, and Friedel opposites were merged. The monoclinic unit cell for 2 contained 16 formula units. The asymmetric unit was therefore divided into four parts, using the SHELXL "RESI" command. The presence of multiple molecules per asymmetric unit suggested 15 accidental cell doubling; however, inspection of the unit cell contents confirmed that the larger cell was warranted as the four independent molecules were, in fact, significantly different in geometry and not simply translational copies. In addition, there were significant intensities for $h \neq 4 \mathrm{~N}$ (which 20 would not have been the case for the smaller unit cell.)

\section{Results}

Labelled, thermal ellipsoid plots for the molecular structures of 2, 3, and 5 are shown in Figs. 1, 3, and 5, respectively, and 25 relevant crystallographic information is given in Table 1.

Table 1. Experimental data for the crystal structure determinations of 2, 3 and 5.

\begin{tabular}{|c|c|c|c|}
\hline & 2 & 3 & 5 \\
\hline Formula moiety & $\mathrm{C}_{24} \mathrm{H}_{26} \mathrm{~N}_{2} \mathrm{O}_{5}$ & $\mathrm{C}_{25} \mathrm{H}_{28} \mathrm{~N}_{2} \mathrm{O}_{6}$ & $\mathrm{C}_{21} \mathrm{H}_{22} \mathrm{~N}_{2} \mathrm{O}_{5}$ \\
\hline Mw. & 422.47 & 452.49 & 382.41 \\
\hline Color, Habit & $\begin{array}{l}\text { colourless } \\
\text { plate }\end{array}$ & $\begin{array}{l}\text { colourless } \\
\text { prism }\end{array}$ & purple prism \\
\hline Crystal system & Monoclinic & Monoclinic & Monoclinic \\
\hline Space group, Z & $\mathrm{P} 2_{1} / \mathrm{c}, 16$ & $\mathrm{Cc}, 4$ & $\mathrm{P} 2{ }_{1} / \mathrm{n}, 4$ \\
\hline $\mathrm{a}, \AA \AA$ & $23.033(3)$ & $15.1881(13)$ & $6.7336(3)$ \\
\hline $\mathrm{b}, \AA$ & $14.036(2)$ & $12.6063(10)$ & $30.1846(12)$ \\
\hline c, $\AA$ & $27.135(4)$ & $12.1356(10)$ & $9.5144(4)$ \\
\hline$\alpha,^{\circ}$ & 90.00 & 90.00 & 90.00 \\
\hline$\beta,{ }^{\circ}$ & $98.508(3)$ & $103.863(3)$ & $96.314(2)$ \\
\hline$\gamma,{ }^{\circ}$ & 90.00 & 90.00 & 90.00 \\
\hline Volume, $\AA^{3}$ & $8676(2)$ & $2255.9(3)$ & $1922.08(14)$ \\
\hline Density, $\mathrm{g} / \mathrm{cm}^{3}$ & 1.294 & 1.332 & 1.321 \\
\hline Temperature, $\mathrm{K}$ & $120(2)$ & $120(2)$ & $120(2)$ \\
\hline $\begin{array}{c}\text { X-ray } \\
\text { wavelength }\end{array}$ & 0.71073 & 0.71073 & 0.71073 \\
\hline$\mu, \mathrm{mm}^{-1}$ & 0.091 & 0.096 & 0.095 \\
\hline$\Theta_{\min }, \circ$ & 2.74 & 2.13 & 2.54 \\
\hline$\Theta_{\max }, \circ$ & 29.52 & 31.50 & 32.36 \\
\hline Reflections & & & \\
\hline $\begin{array}{l}\text { collected } \\
\text { indenendent }\end{array}$ & $\begin{array}{l}87340 \\
23631\end{array}$ & $\begin{array}{c}11726 \\
3756\end{array}$ & $\begin{array}{c}19947 \\
5830\end{array}$ \\
\hline $\begin{array}{l}\text { independent } \\
\text { observed }\end{array}$ & $\begin{array}{c}23631 \\
9797\end{array}$ & $\begin{array}{l}3756 \\
3361\end{array}$ & $\begin{array}{l}5830 \\
4870\end{array}$ \\
\hline $\begin{array}{l}\text { Threshold } \\
\text { expression }\end{array}$ & $>2 \sigma(\mathrm{I})$ & $>2 \sigma(\mathrm{I})$ & $>2 \sigma(\mathrm{I})$ \\
\hline $\mathrm{R}_{1}$ (observed) & 0.0849 & 0.0406 & 0.0408 \\
\hline$w \mathrm{R}_{2}$ (all) & 0.2481 & 0.1082 & 0.1205 \\
\hline
\end{tabular}

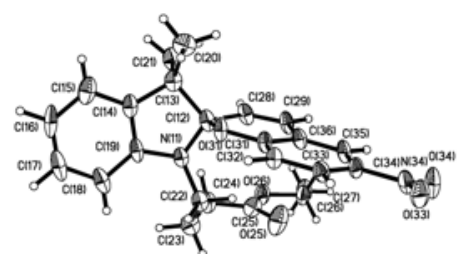

30
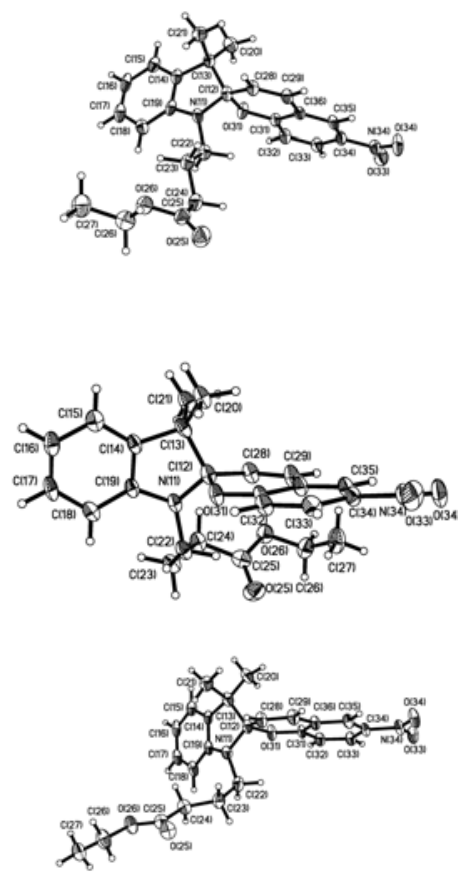

35

Figure 1 The four crystallographically unique molecules in the crystal structure of 2. Ellipsoids at $50 \%$ probability.

The crystal structure determination of 2 reveals that it is in the closed form, and there are four independent spiropyran 40 molecules in the asymmetric unit. They all have similar molecular geometries, with only relatively minor differences in the butanoate chain. The geometry around the indolic nitrogen atom is consistent with an $\mathrm{sp}^{3}$ hybridization. The $\mathrm{C}(8)-\mathrm{N}-\mathrm{C}(1)-\mathrm{C}(2)$ torsion angles (as labelled in Scheme 2) 45 around the indoline moiety are in the range of $27.5-32.0^{\circ}$, which is significantly greater than what is expected from an open form. In each of the four independent molecules, the indolic nitrogen atom is significantly pyramidalized, which reduces conjugation of the $\mathrm{N}$-lone pair and the phenyl ring. ${ }_{50}$ The $\mathrm{N}-\mathrm{C}(1)$ bond lengths in the four independent indoline rings are 1.454(5), 1.451(4), 1.443(4), and 1.449(4) $\breve{A}$ respectively, which is shorter than a typical $\mathrm{C}\left(\mathrm{sp}^{3}\right)-\mathrm{N}\left(\mathrm{sp}^{3}\right)$ bond, but longer than the corresponding $\mathrm{C}-\mathrm{N}$ bond in the open form. The $\mathrm{C}(1)_{\text {spiro }}-\mathrm{O}$ bond lengths, $(1.48-1.50 \AA \mathrm{A})$ are longer ${ }_{55}$ than a typical $\mathrm{C}-\mathrm{O}$ bond, whereas the $\mathrm{O}-\mathrm{C}(9)_{\text {phenyl }}$ bonds (1.35-1.36 $\breve{A})$, are in line with that of a normal exocyclic C-O single bond. Neighbouring spiropyran molecules are arranged in a head-to-tail fashion, Fig 2, to maximize the geometric fit between molecules, and a few $\mathrm{C}-\mathrm{H} \cdots \pi$ interactions also 60 contribute to the exact intermolecular assembly and subsequent orientation of the building blocks in the crystal structure of 2 . 


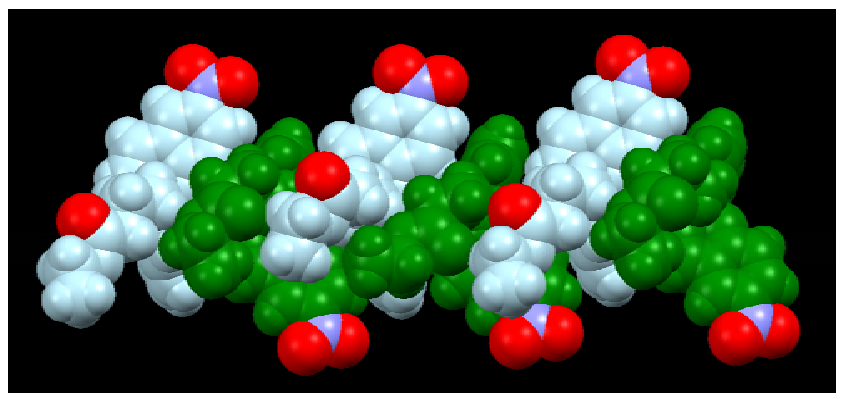

Figure 2 Close packing of molecules in the crystal structure of 2. Ethoxy oxygen atoms (on three molecules) and nitro groups (on all six molecules) are highlighted and, in addition, every other molecule is shown in green to facilitate interpretation of the figure.

The crystal structure determination of $\mathbf{3}$ shows that this compound also exists in the closed form, but in this case there is only one spiropyran molecule in the asymmetric unit, Figure 3. Again, the geometry around the indolic nitrogen 10 atom is consistent with an $\mathrm{sp}^{3}$ hybridization (the $\mathrm{C}(8)-\mathrm{N}-\mathrm{C}(1)$ $\mathrm{C}(2)$ torsion angle (see Scheme 2) around the indoline moiety is $28^{\circ}$ ). The $\mathrm{N}-\mathrm{C}(1)$ bond length in the indoline ring is 1.451(2) $\breve{A}$, which again is between that of a typical $\mathrm{C}\left(\mathrm{sp}^{3}\right)$ $\mathrm{N}\left(\mathrm{sp}^{3}\right)$ bond and the corresponding $\mathrm{C}-\mathrm{N}$ bond in the open 15 form. Finally, the $\mathrm{C}(1)_{\text {spiro }}-\mathrm{O}$ bond length, 1.483(2) $\breve{A}$ and the O-C $(9)_{\text {phenyl }}$ bond, $1.350(2) ~ \check{A}$, are consistent with those observed for the molecular geometries in the structure of 2 .

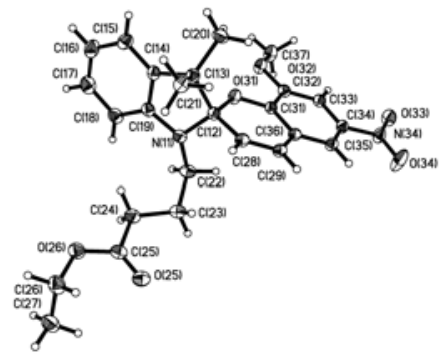

Figure 3 The molecular structure of 3 . Ellipsoids at 50\% probability.

20

Neighbouring molecules in the crystal structure of $\mathbf{3}$ are closepacked in a very tight manner which is reflected in the relatively high density of the compound, $1.33 \mathrm{~g} \mathrm{~cm}^{-3}$ (calc).

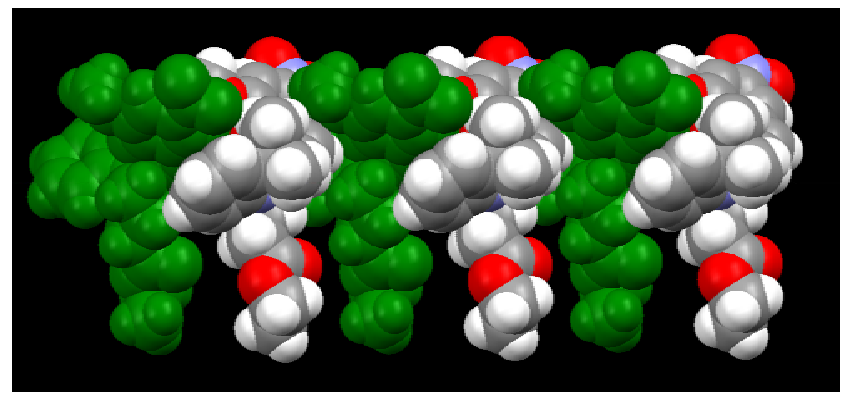

${ }_{25}$ Figure 4 Close packing of molecules in the crystal structure of 3. Every other molecule is shown in green to facilitate interpretation of the figure.

In this case adjacent molecules along the c-axis are staggered (not head-to-tail), in order to better accommodate the methoxy-group on the phenyl ring.
Surprisingly, the crystal structure determination of $\mathbf{5}$ showed that the this compound exists in the the open, zwitterionic (bipolar) form, Figure 5. The geometry around the indolic nitrogen atom is now close to planar $(\mathrm{C}(8)-\mathrm{N}-\mathrm{C}(1)-\mathrm{C}(2)$ 35 torsion angle is $\left.3.4(1)^{\circ}\right)$ and the $\mathrm{N}-\mathrm{C}(1)$ bond distance is 1.336(1) $\breve{A}$, which is closer to a conventional $\mathrm{C}=\mathrm{N}$ bond. The exocyclic $\mathrm{C}(9)-\mathrm{O}$ bond distance involving the phenolate

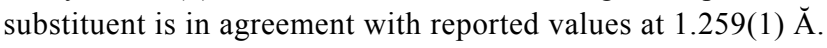

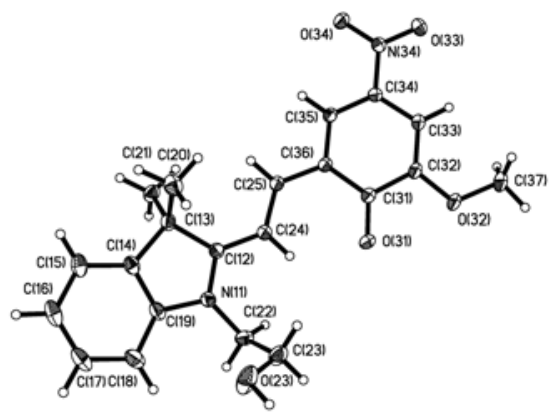

40 Figure 5 The molecular structure of 5 . Ellipsoids at $50 \%$ probability.

The presence of a strong hydrogen-bond donor (the $-\mathrm{OH}$ group) and a powerful hydrogen-bond acceptor (the phenolate moiety), introduces a structure-directing hydrogen bond, which produces a chain of zwitterions, Figure 6.

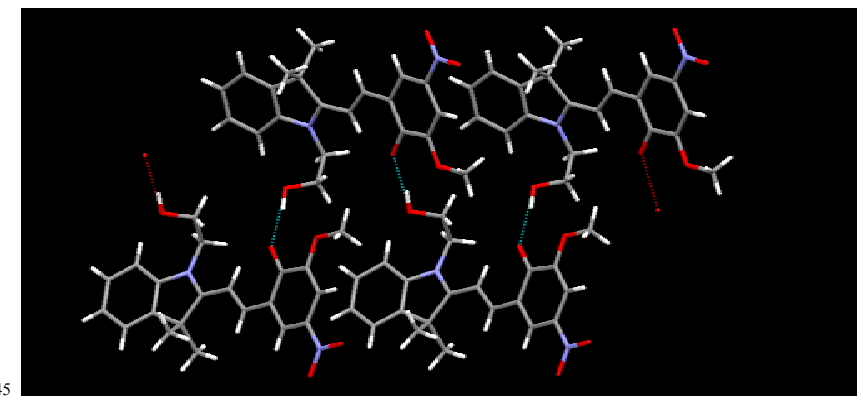

Figure 6 An infinite chain in the structure of 5 assembled via chargeassisted $\mathrm{O}-\mathrm{H} \cdots \mathrm{O}$ hydrogen bonds.

\section{${ }_{50}$ Discussion}

A comparison of the most important geometric parameters in the crystal structures of $\mathbf{2}$ and $\mathbf{3}$ with data from the CSD for 32 previously reported closed structures is shown in Table 2 with the labelling scheme shown in Scheme 2. 
<smiles>CN1CCCC1(C)C(C)(C)c1ccccc1Oc1ccccc1</smiles><smiles>C[N+]1=C([Ge]=Cc2ccccc2[O-])C(C)(C)c2ccccc21</smiles>

Scheme 2

Table 2. Selected geometric parameters for molecular structures of 5 spiropyrans (labelling as shown in Scheme 2)

\begin{tabular}{|c|c|c|c|}
\hline Parameter & 2 & 3 & $\begin{array}{l}\text { Lit. average } \\
\text { Lit. range }\end{array}$ \\
\hline $\mathrm{N}-\mathrm{C} 1 / \mathrm{A}$ & $\begin{array}{l}1.454(4) \\
1.451(4) \\
1.443(4) \\
1.449(4)\end{array}$ & $1.451(2)$ & $\begin{array}{c}1.45 \\
1.43-1.48\end{array}$ \\
\hline $\mathrm{C} 1-\mathrm{C} 10 / \mathrm{A}$ & $\begin{array}{l}1.496(5) \\
1.492(4) \\
1.511(5) \\
1.490(5)\end{array}$ & $1.499(2)$ & $\begin{array}{c}1.50 \\
1.47-1.53\end{array}$ \\
\hline$\overline{\mathrm{C} 1-\mathrm{O} / \mathrm{A}}$ & $\begin{array}{l}1.495(4) \\
1.497(4) \\
1.482(4) \\
1.489(4)\end{array}$ & $1.483(2)$ & $\begin{array}{c}1.48 \\
1.45-1.51\end{array}$ \\
\hline$\overline{\mathrm{O}-\mathrm{C} 9 / \mathrm{A}}$ & $\begin{array}{l}1.349(4) \\
1.360(4) \\
1.356(4) \\
1.356(4)\end{array}$ & $1.353(3)$ & $\begin{array}{c}1.36 \\
1.34-1.38\end{array}$ \\
\hline $\mathrm{C} 8-\mathrm{N}-\mathrm{C} 1-\mathrm{C} 2 /^{\circ}$ & $\begin{array}{l}31.9(3) \\
30.6(3) \\
29.6(3) \\
27.5(3)\end{array}$ & $28.3(2)$ & $\begin{array}{c}28 \\
18-32^{\circ}\end{array}$ \\
\hline
\end{tabular}

10

The data in Table 2 show that the molecular geometries of the closed spiropyrans reported herein deviate very little from the average values based on 32 previously reported compounds. This indicates that different substituents on the phenolic 15 backbone have little effect on bond lengths and bond angles even though they are, electronically, very important for stabilizing the zwitterionic open form. The reverse reaction (merocyanine $\rightarrow$ spiropyran) is also very facile which explains the paucity of strutural data for the open form.
20 A comparison of the most important geometric parameters in the crystal structure of 5 (in the open merocyanine form) with data from the CSD for the four previously reported structures is shown in Table 3 (labels shown in Scheme 2).

25 Table 3. Selected geometric parameters for molecular structures of merocyanins (labelling from Scheme 2)

\begin{tabular}{|c|c|c|}
\hline Parameter & $\mathbf{5}$ & Lit. range \\
\hline $\mathrm{N}-\mathrm{C} 1 / \check{\mathrm{A}}$ & $1.336(1)$ & $1.32-1.34$ \\
\hline $\mathrm{C} 1-\mathrm{O} / \check{\mathrm{A}}$ & $\mathrm{N} / \mathrm{A}$ & $\mathrm{N} / \mathrm{A}$ \\
\hline $\mathrm{O}-\mathrm{C} 9 / \check{\mathrm{A}}$ & $1.259(1)$ & $1.23-1.26$ \\
\hline $\mathrm{C} 1-\mathrm{C} 10 / \check{\mathrm{A}}$ & $1.414(1)$ & $1.41-1.42$ \\
\hline $\mathrm{C} 10-\mathrm{C} 11 / \check{\mathrm{A}}$ & $1.370(1)$ & $1.34-1.36$ \\
\hline $\mathrm{C} 8-\mathrm{N}-\mathrm{C} 1-\mathrm{C} 2 /^{\circ}$ & $3.36(1)$ & $0-5$ \\
\hline
\end{tabular}

Despite the fact that the CSD only contains four purely organic merocyanine structures, it is clear that for the most 30 part there are minimal differences in terms of molecular geometry within this group of compounds.

Obviously, the lifetime of the open merocyanine form is an important aspect of the incorporation of these molecules in devices, which makes the rarity of structures such as $\mathbf{5}$ very 35 intriguing. The question is, why are there so few crystal structures of merocyanines?

Typically crystals of the merocyanine form have been obtained via recrystallization from ethanol under UV radiation. ${ }^{18}$ There is only one reported example of a 40 merocyanine obtained via recrystallization in the dark from $\mathrm{DMF} / \mathrm{CH}_{2} \mathrm{Cl}_{2} .{ }^{19}$ However, the same compound was also obtained in the closed form ${ }^{20}$ by slow evaporation from methanol/dichloromethane $(1: 10)$ in dark.

Table 4. Crystallization conditions and absence/presence of hydrogen45 bond (HB) moieties on a series of spiropyrans.

\begin{tabular}{|c|c|c|c|c|c|}
\hline CODE & Open forms & HB & Code & $\begin{array}{l}\text { Closed } \\
\text { forms }\end{array}$ & HB \\
\hline BAPNAH & Acetone/ambient & No & & & \\
\hline BETGEM & Ethanol/UV & $\begin{array}{l}\text { Yes } \\
\text { (solvent) }\end{array}$ & & & \\
\hline FAFPOR & Ethanol/UV & No & & & \\
\hline GUWFEJ & $\begin{array}{l}\text { DMF- } \\
\mathrm{CH}_{2} \mathrm{Cl}_{2} / \text { dark }\end{array}$ & $\begin{array}{l}\text { Yes } \\
\text { (solvent) }\end{array}$ & & & \\
\hline \multirow[t]{4}{*}{5} & $\mathrm{MeOH} /$ ambient & Yes & & & \\
\hline & & & IHOFOA & $\begin{array}{l}\text { Ethanol- } \\
\text { heptane/ } \\
\text { ambient }\end{array}$ & Yes \\
\hline & & & NACBOJ & $\begin{array}{l}\mathrm{MeOH}- \\
\mathrm{CH}_{2} \mathrm{Cl}_{2} / \\
\text { ambient }\end{array}$ & \\
\hline & & & SISJEK & $\begin{array}{l}\text { Isopropanol/ } \\
\text { ambient }\end{array}$ & \\
\hline
\end{tabular}

As the open form is zwitterionic with one phenolate moiety, it is reasonable to expect that polar solvents and any electron 50 withdrawing substituent will stabilize this form and extend its lifetime. In fact, all five crystallographically characterized open forms have a nitro group, para to the phenolate moiety, Table 4. However, there are also several para-nitro species that have been obtained in the solid state in the closed ${ }_{55}$ spiropyran form. It has been speculated that two nitro groups are needed to stabilize the anion (two of the four previously 
reported merocyanines did have two such substituents, the remaining two contained a nitro and a bromo substituent)), ${ }^{20}$ but the crystal structure of $\mathbf{5}$ demonstrates that this is not the case. Furthermore, the role of the solvent seems to be less 5 important when it comes to isolating open forms in the solid state as the vast majority of the 32 closed forms reported in the CSD were crystallized from polar solvents such as ethanol, methanol, or acetone.

It is however possible that there is another component, which 10 has not been addressed to any great extent, that can be used to influence the balance between the neutral and the bipolar form in the solid state. The stability of the open form may, in fact, be enhanced by the presence of a substituent on the indole nitrogen atom (or on other parts of the molecule) capable of 15 forming strong intermolecular hydrogen bonds to the phenolate oxygen atom of a symmetry related molecule. This acceptor site is obviously not present in the closed form and it is concievable that the balance between the open- and closed form in the solid state is controlled by a hydrogen-based 20 supramolecular switch. In 5, the hydroxy group off the indole nitrogen atom acts as a hydrogen-bond donor to the phenolate site and in the crystal structure of 3-\{3,3-dimethylspiro[2,3dihydro-1H-indole-2,3'-(3'H-naphtho[2,1-b][1,4]oxazin)]-1yl\}propionic acid carboxylic acid (GUWFEJ, Table 5) the 25 acid can stabilize the the phenolate in solution through strong charge-assisted $\mathrm{O}-\mathrm{H}^{\prime} \cdots \mathrm{O}^{-}$hydrogen bonds.
Table 5. Molecular structures and CSD refcodes for reported crystal structures of organic spiropyrans (open forms)

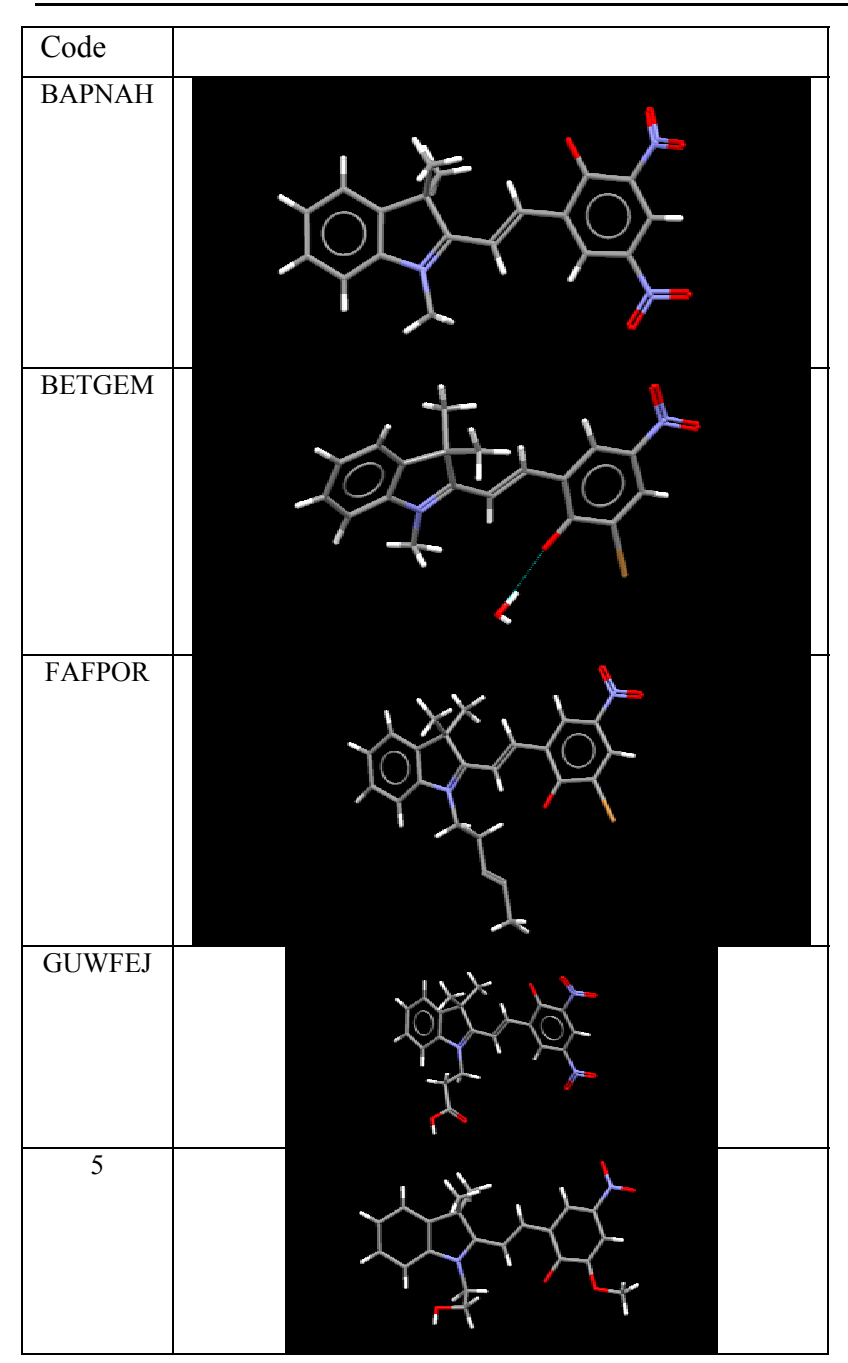

Interestingly, in the crystal structure of the open 1-(1,3,360 trimethylindolium-2-yl)-2-(2-(6-bromo-4-nitrophenolate))ethylene (BETGEM, Table 5) a compound that does not carry a strong hydrogen-bond donor, the phenolate oxygen atom is neverthless engaged in a hydrogen bond to an included water molecule. The fourth member of family of open forms ${ }_{65}$ (FAFPOR, Table 5), was obtained via crystallization under UV radiation. The remaining known open form (BAPNAH), whose structure was noted by authors as being unusual, ${ }^{12 a}$ carried two stabilizing nitro substituents on the phenyl backbone.

${ }_{70}$ On the other hand, only three of the 32 known closed forms contain a strong hydrogen-bond donor site. In 1,3,3trimethyl-5'-hydroxy-7'-formyl-spiro-indolin-2,2'-

(2H)chromene SISJEK, Table 6), the hydroxy group is engaged in an intramolecular hydrogen bond to an adjacent 75 formyl moiety and is therefore not available for intermolecular interactions. 
Table 6. Molecular structures and CSD refcodes for reported crystal structures of organic spiropyrans (closed forms) that are also functionalised with strong hydrogen-bond donors.

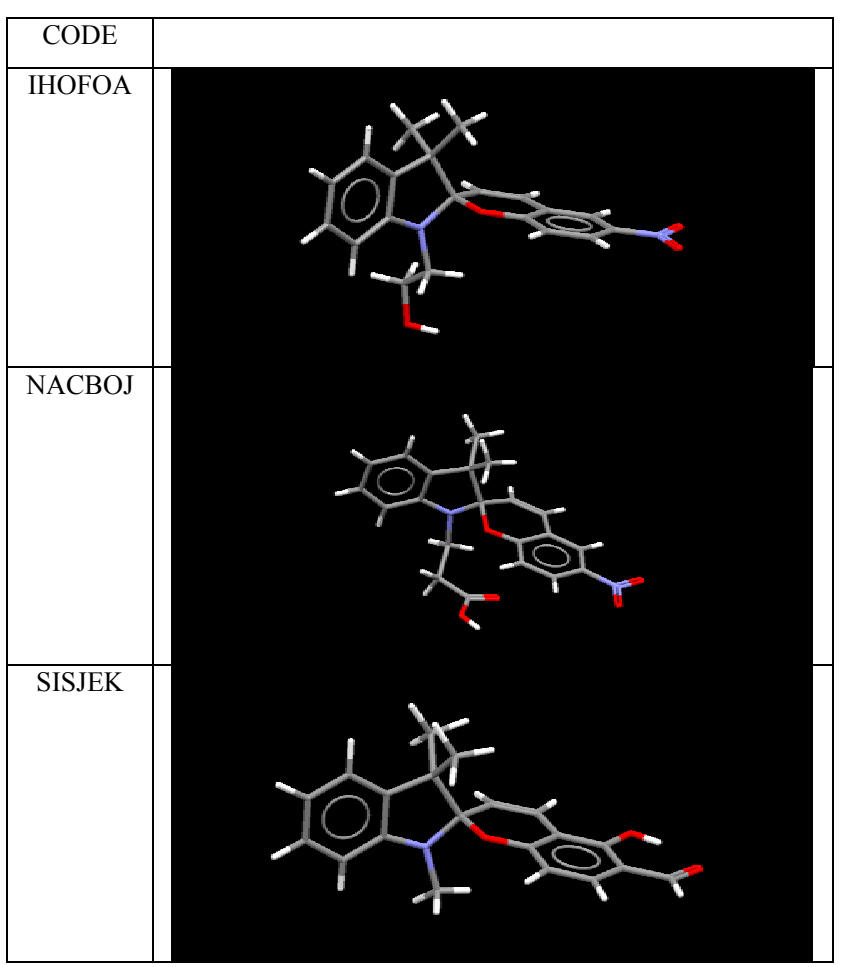

5 This leaves $\quad(\mathrm{R} / \mathrm{S})-2-\left(3^{\prime}, 3^{\prime}\right.$-dimethyl-6-nitro-3'Hspiro(chromene-2,2'-indol)-1'-yl)ethanol ethanol n-heptane solvate $^{21}$ (IHOFOA, Table 6) and 3-\{3,3-dimethyl-6'nitrospirol[2'H-chromene-2,2'-(2,3-dihydro-1H-indole)]propanoic acid (NACBOJ, Table 5) which contains head-to10 head carboxylic acid dimers in the solid state. Both appear in the closed form despite the presence of hydrogen-bond donors, which indicates that the presence of such moieties alone are not sufficient to ensure an open merocyanine structure.

15 Although it is too early to state unambiguously how important intermolecular hydrogen bonds are in this context (due to the lack of structural information), it is certainly plausible that hydrogen-bond based non-covalent stabilization of the phenolate oxygen atom may be a significant factor for 20 controlling the spiropyran-merocyanine balance. We are currently undertaking a systematic synthesis-structural study to test this hypothesis in order to establish if it is possible to influence the photochromic behaviour of this family of compounds not just via covalent means, but also through 25 supramolecular chemistry.

\section{Acknowledgements}

We are grateful for financial support from Science Foundation Ireland (PIYRA 07/YI2/I1052, and SURE), Trinity College 30 Dublin (Trinity Award to MN) and ACS-PRF (\#46011-AC1).

${ }^{\text {a }}$ Christer B. Aakeröy, Evan P. Hurley, John Desper

Department of Chemistry, Kansas State University, Manhattan, ${ }_{35} \mathrm{KS}, 66506$, E-mail: aakeroy@,ksu.edu b Silvia Giordani*, Manuel Natali, Antoin Douglawi

Department of Chemistry/CRANN, Trinity College, Dublin, Ireland. E-mail: giordans@tcd.ie.

Electronic Supplementary Information (ESI) available: CIF files. See 40 DOI: $10.1039 / \mathrm{b} 000000 \mathrm{x} /$

\section{Notes and references}

${ }^{1}$ E. Fischer and Y. Hirschberg, J. Chem. Soc., 1952, 4522.

${ }^{2}$ K. Fries, S. Samanta, S. Orski, J. Locklin, Chem. Commun., 2008,6288.

${ }^{3}$ F.M. Raymo, S. Giordani, J. Am. Chem. Soc., 2001, 123, 4651.

${ }^{4}$ Y. Hirschberg, J. Am. Chem. Soc., 1956, 78, 2304.

5 (a) C. Tu, A. Y. Louie, Chem. Commun., 2007, 1331; (b) T. Stafforst, D. Hilvert, Chem. Commun., 2009, 287; (c) R.J. Byrne, S. E. Stitzel, D. Diamond, J. Mater. Chem., 2006, 14,1332; (d) S. Yagai, M. Higashi, T. Karatsu, A. Kitamura, Chem. Commun., 2006, 1500.

${ }^{6}$ H. Bouas-Laurent and H. Durr, Photochromism: Molecules and Systems, 2003, Wiley.

${ }^{7}$ P. Vandewye, J. Hoefnage, G. Smets, Tetrahedron, 1969, 25, 3251.

${ }^{8}$ R. Rosario, D. Gust, M. Hayes, J. Springer, A. A. Garcia, Langmuir, 2003, 19, 8801 .

${ }^{9}$ S. Scarmagnani, Z. Walsh, C. Slater, N. Alhashimy, B. Paull, M. Macka, D. Diamond, J. Mater. Chem., 2008, 18, 5063.

${ }^{10} \mathrm{~S}$. Bernard and P. Yu, Adv. Mater. 2000, 12, 48. O. Godsi, U. Peskin, M. Kapon, E. Natan, and Y. Eichen, Chem. Commun, 2001, 2132.

${ }^{11}$ F.H. Allen, Acta Crystallogr. 2002, B58, 380.

12 (a) J.Hobley, V.Malatesta, R.Millini, L.Montanari, W.O.N.Parker Jr. Phys.Chem.Chem.Phys.(PCCP) 1999, 1, 3259; (b) W. Zou, P. Chen, Y. Gao and J. Meng Acta Cryst. 2003, E59, o337-o339.

13 S.M. Aldoshin, L.O. Atovmyan, Izv. Akad. Nauk SSSR Ser. Khim. 1985, 2016 (the compound was crystallized under UV radiation).

14 S.M.Aldoshin, L.O.Atovmyan, O.A.D'yachenko, M.A.Gal'bershtam, Izv.Akad.Nauk SSSR,Ser.Khim., 1981, 2720.

${ }^{15}$ APEXII v1.27, (C) 2005, Bruker Analytical X-ray Systems, Madison, WI.

16 SAINT v6.02, (C) 1997 - 1999, Bruker Analytical X-ray Systems, Madison, WI.

${ }^{17}$ SHELXTL v5.10, (C 1997, Bruker Analytical X-ray Systems, Madison, WI.

18 S.M. Aldoshin, Russ. Chem. Rev, 1990, 59, 1144.

${ }^{19}$ W. Zou, P. Chen, Y. Gao, J. Meng, Acta Cryst. E, 2003, E59, 0337. In the lattice, a DMF molecule is associated with the carboxylic acid, but this does not preclude extensive phenolate-acid interactions in solution.

${ }^{20}$ W.X. Zou, H.M. Huang, Y. Gao, T. Matsuura, J.B. Meng, Structural Chem., 2004, 15, 317.

${ }^{21}$ F.M.Raymo, S.Giordani, A.J.P.Williams, J.Org.Chem., 2003, 68, 4158. 